ARTICLES

\title{
Evolution of the vulture population on a Mediterranean island. The Sardinian
} instance (Italy).

\author{
Marcello Grussu* \& Sardinian Ornithological Group \\ C.P. $160 / \mathrm{C}$ \\ 09045 Quartu Sant'Elena, Cagliari (Italy) \\ *Email: porphyrio@ tiscali.it
}

http://dx.doi.org/10.4314/vulnew.v76i1.2

\begin{abstract}
On the Italian island of Sardinia at the beginning of the $20^{\text {th }}$ century there was still an established population of the Bearded Vulture (about 35 pairs), Black Vulture (about 150 pairs) and the Griffon Vulture was "very common". However, in the early decades of the $20^{\text {th }}$ century there was a rapid and catastrophic reduction of the vulture populations on Sardinia, with the extinction of Bearded Vulture (1968-69) and the Black Vulture (1961), and the contraction of the population of Griffon Vulture (10001400 birds in 1945 to 100 -140 birds in 1975 and 12 breeding pairs in 2007). The collection of skins and eggs, followed by hunting, poaching, killing and the use of poisoned baits for pest control were the main causes of the decline of the vultures on Sardinia. These causes were accompanied by an increase of disturbance at the breeding sites, and by a gradual decrease of pastoralism, which has led to a reduction in food availability. More recently, there have been unsuccessful attempts to reintroduce Bearded Vultures and Black Vultures, whereas after various restocking and greater protection projects, the Griffon Vulture population has increased (to 57 pairs and 230-250 birds in 2019). The Egyptian Vulture bred in Sardinia for the first time in 2019. Currently, collection and killing of vultures, and the legal use of poisoned baits have all been removed in Sardinia and the environmental situation now seems appropriate for new attempts to reintroduce the two extinct species.
\end{abstract}

\section{Introduction}

The conservation status of most Old World vultures is deteriorating rapidly and 11 of the 16 species are classified as globally threatened (BirdLife 2018). In Europe, with the exception of some species in a few areas (for example the Griffon Vulture Gyps fulvus in Spain) vulture population declines likely began as early as the mid 19th century and in many countries several species have become extinct or are at the critical lower limit of the population (BirdLife 2000, 2004, 2018; Ogada et al. 2011).

In Italy outside Sardinia, the last breeding record of the Bearded Vulture Gypaetus barbatus of the autochthonous population was recorded at the beginning of the $20^{\text {th }}$ century in the Alps, the Griffon Vulture had disappeared by 1965 in Sicily, while the Black Vulture Aegypius monachus had always been limited to the island of Sardinia (Brichetti et al. 1982, Iapichino \& Massa 1989, Brichetti \& Fracasso 2003). Until the mid 1900s Sardinia was the only area in Italy where these three of the four European vulture species still bred. In the following decades in Sardinia there was a dramatic reduction of the vulture population. The Bearded Vulture and the Black Vulture were extinct by the 1960s/70s and there was a crash of the Griffon Vulture population, such that in the last decades of the $20^{\text {th }}$ century it 
was limited to a few dozen pairs and 70-100 birds (Grussu 2001, Schenk et al. 2008). In the period 1986-2020 there were several projects aimed at reintroducing or restocking of the Bearded Vulture and the Griffon Vulture (Schenk et al. 2008, Fasce \& Fasce 2009; Project LIFE 14 NAT/IT/000484), with a result that was not always positive. In contrast, in 2019 there was recorded the first breeding of the Egyptian Vulture Neophron percnopterus; a species that previously was known only as very rare vagrant (Grussu 2001).

In this paper I summarise the recent and historic declines of vultures in Sardinia, the evolution of the population, the dangers to their survival on the island and the projects carried out for their protection.

\section{Study area}

Sardinia is located in the centre of the western Mediterranean, approximately $170 \mathrm{~km}$ from mainland Italy and $160 \mathrm{~km}$ from Tunisia (Figure
1). With an area of $24,098 \mathrm{~km}^{2}$, after Sicily it is the largest island of the Mediterranean and it encompasses a variety of habitats. Mountains and hilly areas make up $72 \%$ of the island, which has an average elevation of $345 \mathrm{~m}$ and a maximum of $1834 \mathrm{~m}$ asl (Gennargentu Massif). Lowlands and rocky uplands occupy $18 \%$ of the island. Sardinia's coasts are mostly rocky and partially lined with cliffs. Near these areas, especially in the south and in the west, swamps and lagoons often occur. Mediterranean maquis (shrubby sclerophyll formation, including tall fruticeae) and forests are the major components of the landscape. In the forests, Mediterranean woods prevail (Quercus ilex and Quercus pubescens) and subMediterranean woods also occur, typical of the colder inland environments. The climate can be defined as warm-temperate and two-seasonal; annual average rainfall is $500 \mathrm{~mm}$ on the southern coasts and $900 \mathrm{~mm}$ in the highest mountain areas of the interior (Arrigoni 1968, Camarda et al. 2015).

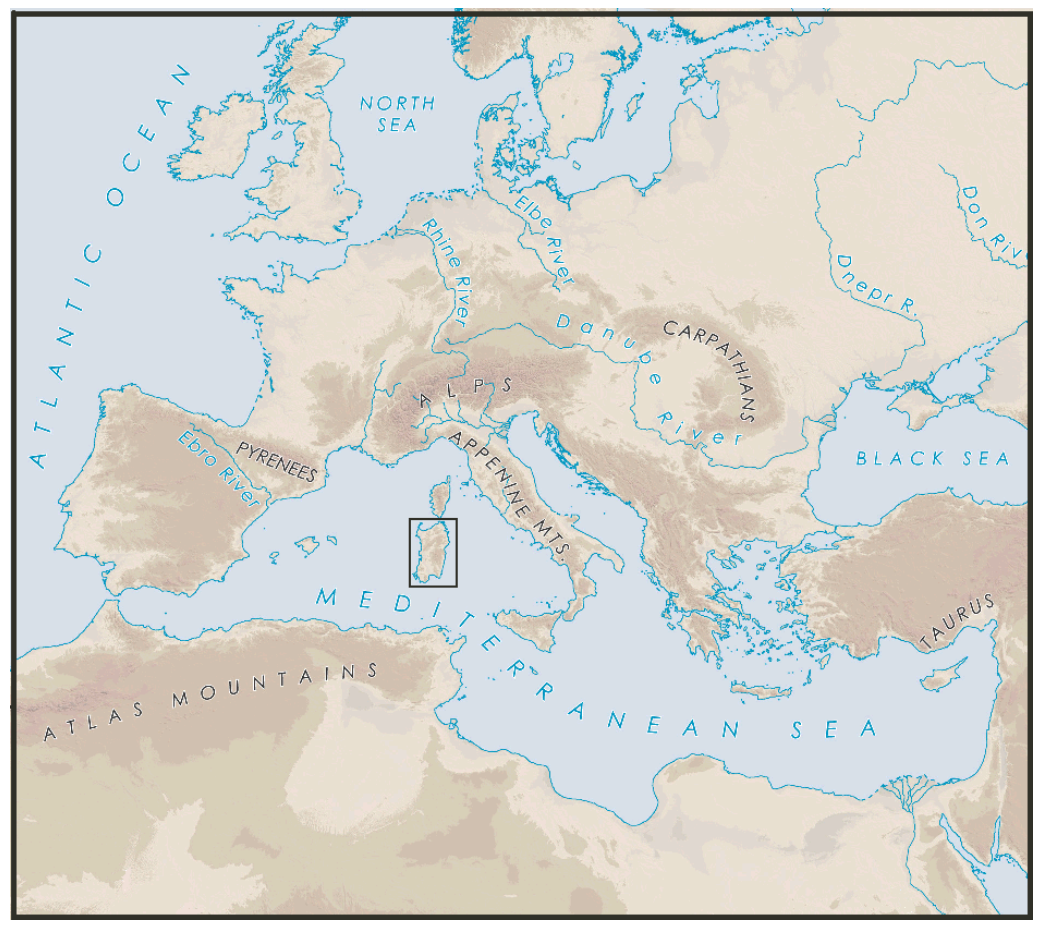

Figure 1: Location of the island of Sardinia 


\section{Population dynamics of the vultures}

\section{Bearded Vulture Gypaetus barbatus}

Considered "common" in some areas of the island at the end of 1800s (Brooke 1873, Martorelli 1884), up to the beginning of the 20th century the Bearded Vulture was present as a breeding species in most of the mountain systems of Sardinia with a population of about 35 pairs and 125 birds. Following a rapid decline, the species became extinct as a breeding species in the late 1960s mainly due to collecting. In fact, in the $19^{\text {th }}-20^{\text {th }}$ centuries Sardinia was one of the regions of the range of the Bearded Vulture most frequented by the collectors of this species (Hiraldo et al. 1979). Over 120 birds from Sardinia collected in the period 1820-1962 are stuffed in the museums of the world, whereas only historically sporadic episodes of single birds killed by poisoning are known (Schenk et al. 2004, Grussu unpublished). The last breeding record occurred in 1968-69 in the central part of the island close Orgosolo/ Nuoro, when a pullus was robbed from the nest and in 1969 one of the adults of this pair was killed in the nest and then sold to collectors (D. Ruiu, personal communication). Although unlikely, it is possible that other breeding pairs may have existed in the years immediately afterwards in this area of Sardinia and in the mountains to the southeast (Sarrabus area) of the island (D. Ruiu and A. Monni personal communication). For some years afterwards there were sporadic sightings of single birds of the autochthonous relict population and in 1972, in the north of the island, the was a pair of adults that apparently did not breed for more than a decade (Schenk 1974, Grussu \& Seguin 2015). The species is considered to have disappeared as a breeding bird from the island in the 1970s (Grussu 2001, Schenk et al. 2004). In the period 19802014 there have been 11 distinct sightings (10 of single birds and one record of two birds together) of Bearded Vultures in Sardinia. The age of these birds however, combined with the observation dates and the changing status of the species in Europe suggest that the majority, if not all, of these birds came from the nearby $(7 \mathrm{~km})$ island of Corsica/ France (Grussu \& Seguin 2015, Seguin \& Grussu 2017). In Corsica, a small population of the species is still present (five pairs in 2017), but this population is geographically isolated with a low (and decreasing) breeding rate and a rather high extinction risk (Seguin et al. 2010, Seguin \& Grussu 2017). These movements between Corsica and Sardinia may appear strange, given the species is essentially resident, with juveniles and immatures staying mainly within their natal mountain system (Cramp \& Simmons 1977, Forsman 1999). However, for this species which can make daily several tens of kilometers, historically Corsica and Sardinia were probably inhabited by a single population with exchanges between the individuals of the two islands (Grussu \& Seguin 2015, Seguin \& Grussu 2017). Genetic studies on individuals collected in the $19^{\text {th }}$ century and preserved in museums show that at that time there were exchanges between the individuals within the meta-population present in Europe (Gautschi 2001, Godoy et al. 2004), but the negative trend of European populations during the $20^{\text {th }}$ century brought about a geographical isolation of the birds on Corsica and Sardinia (Fasce et al. 1989, Seguin et al. 2010).

In 2006, as part of the "Bearded Vulture Reintroduction Project", the Foundation for the Conservation of the Bearded Vulture (FCBV) and some Provincial Administrations of Sardinia began a project for the reintroduction of the species on the island aimed for a period of at least five years to release 2-3 birds per year. In spring 2008, the first three individuals were released in the mountains of the center of the island, but after about a month all these birds were found dead due 
to poisoning. As a consequence of the tragic reintroduction project are the only possibilities for outcone of this release, the project was aborted (Fasce \& Fasce 2009).

a re-colonization of the Bearded Vulture to

An increasing population in Corsica (where a of the autochthonous population of the species in restocking project is currently underway; J-F. Sardinia are highlighted in Figure 2.

Seguin personal communication) or a specific

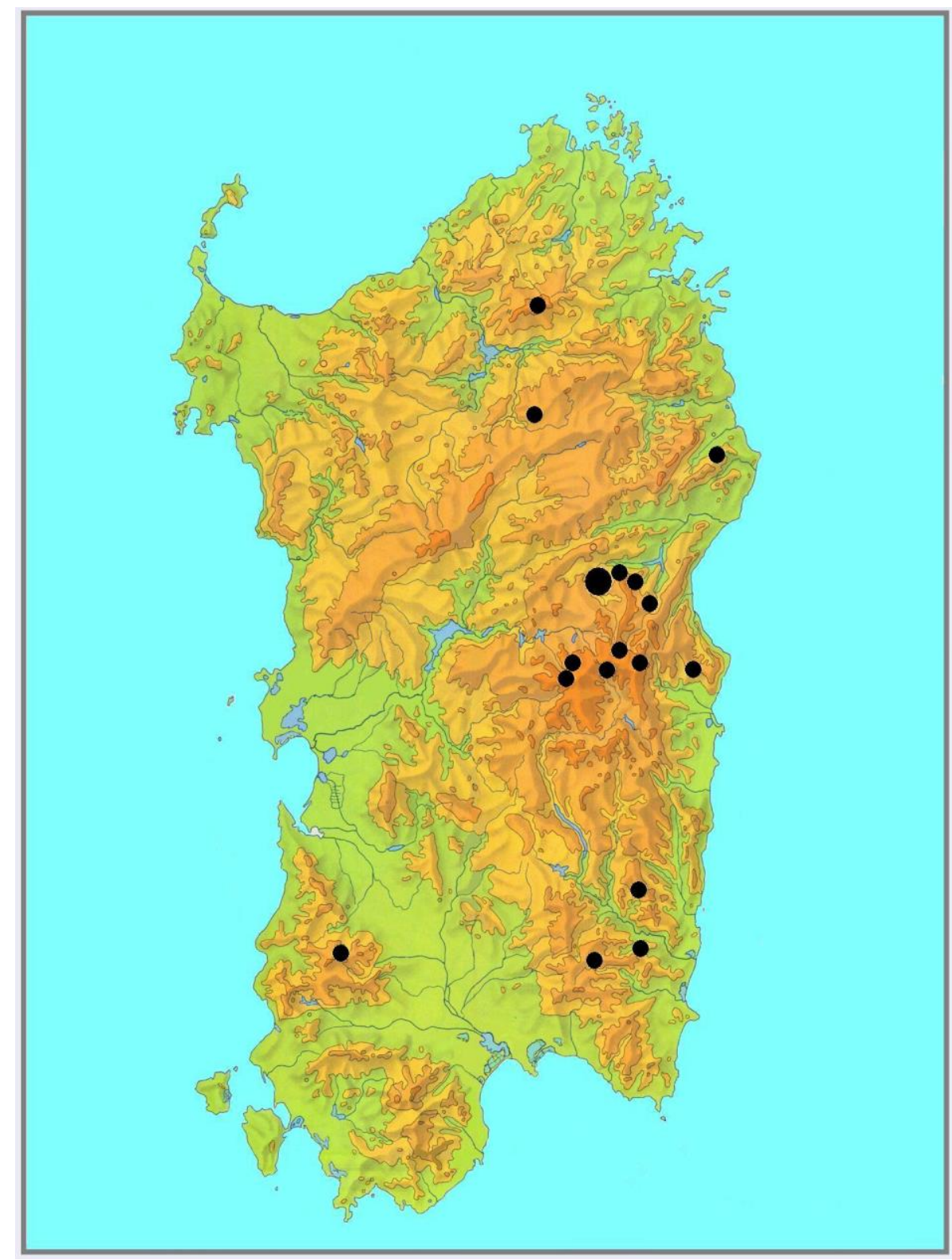

Figure 2: Last breeding records (big point) and last sightings sites (small points) of the autochthonous population of Bearded Vulture Gypaetus barbatus in Sardinia, period 1960-1979. Other later records (post 1980 year) refer to individuals originating from Corsica Island. 


\section{Black Vulture Aegypius monachus}

In the late 1800s, the Black Vulture was considered "widespread in all mountains" and locally also as "the most common of vultures" (Cara 1842, Giglioli 1890). Brooke (1873), in the southeast of the island, found 3-4 occupied nests close together and probably more than 150 pairs were present on the island (Schenk \& Genero 1996). Around the middle of the $20^{\text {th }}$ century, the species was still present in over $50 \%$ of the territory of island and relatively abundant in the mountain areas of the central (Gennargentu Mts.) and northern eastern parts (Monte Ferru/ Bosa), with a probable population of several dozens of birds and 25-35 breeding pairs. In these two areas groups of 4 to 10 individuals were regularly observed together with Griffon Vultures, and numerous individuals were regularly captured and sold to collectors (Schenk 1974, 1976, Schenk \& Genero 1996, Grussu unpublished). Similar to the Bearded Vulture, the decline of Black Vultures in Sardinia occurred rapidly; in the early 1960s the total population on the island probably did not exceed ten individuals and the last breeding record was in 1961, when a pullus was robbed from the nest at Urzulei/ Nuoro (Schenk 1976, Grussu 2001, U.F. Foschi and P. Carroni personal communication). Subsequently, sporadic observations of single individuals continued, with the last record from 1975 in the mountains of
Oliena/ Nuoro (Schenk 1976); but the species is considered extinct in the 1960s from the island as breeding bird (Grussu 2001).

Subsequent records of this species in Sardinia are due to individuals originating from zoos or reintroduction projects and released to the wild. In 1981, two individuals originating from private zoos were released by the LIPU/ BirdLife inside the breeding area of Griffon Vultures in the northwest of the island, where the Black Vulture nested until the 1950s. One of these individuals was found dead after a few weeks and the other was recorded for few years (perhaps until 1986); while in the winter 2005-spring 2006 an immature from the reintroduction project in southern France was seen in the northwest of the island (P. Carroni, G. Prola and F. Nurchi personal communication). Since then there are no other records of the Black Vulture in Sardinia. In Europe, the Black Vulture is mainly resident and does not migrate, with the closest colonies to Sardinia located in the Balearic Islands and the south of France (Cramp \& Simmons 1980, Forsmann 1999, Ferguson-Lees \& Christie 2005). Currently, it seems unlikely that a natural colonization of the species in Sardinia will occur. This being the case, a specific reintroduction project offers the highest possibility of bringing back this species to the island.

The last breeding and observation sites of the autochthonous population of the species in Sardinia are highlighted in Figure 3. 


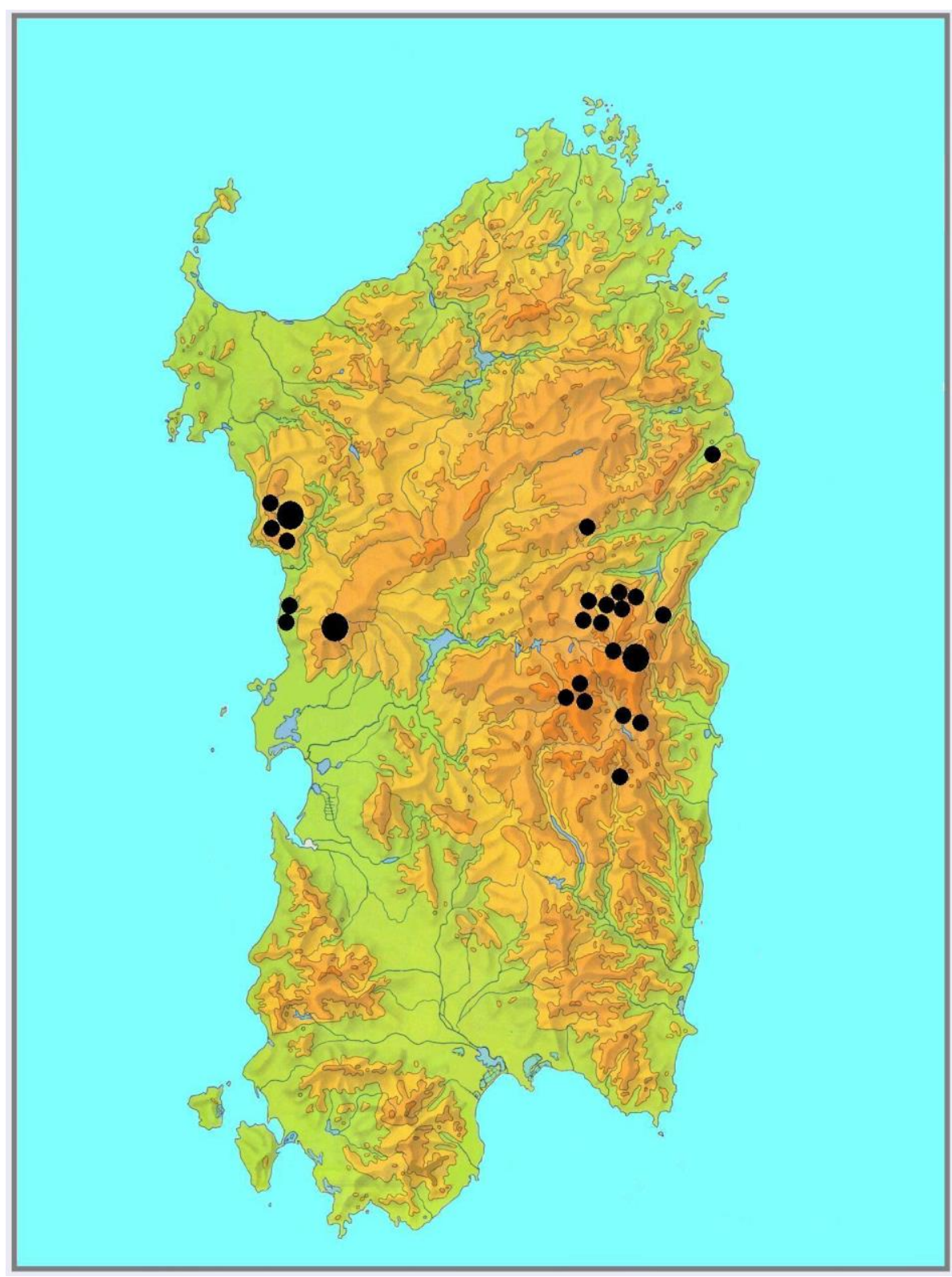

Figure 3: Last breeding records (big point) and last sightings sites (small points) of the autochthonous population of Black Vulture Aegypius monachus in Sardinia, period 1950-1980. Other later records (post 1980 year) refer to single released birds.

\section{Griffon Vulture Gyps fulvus}

The Griffon Vulture was considered "very common" at the end of the $19^{\text {th }}$ century, with several records of groups of over 100 individuals together in many areas of the island (Salvadori 1864, Martorelli 1884). The negative dynamics of this species in Sardinia in the following decades is similar to that of the other vultures. Around the middle of the $20^{\text {th }}$ century, there were probably still 1000-1400 birds of the species in Sardinia, which reduced to 300-400 in 1965 and 100-140 in 1975 (Schenk 1976). This dramatic decline is due to a combination of rapid changes and human interference in the ecosystem: mainly with extensive and uncontrolled use of pesticides. After 1975, some restocking projects occurred in the period 1986-95 which released to the wild a total of 68 individuals imported from Spain and France. These actions have slowed the extinction of the 
species in Sardinia, but the population was reduced to 31 breeding pairs (c. 125 birds) in 1995 and to 12 breeding pairs (65 birds) in 2007 that lived in a restricted area of the northeastern coast (Schenk 1976, Schenk et al. 2008). This ongoing collapse of the Griffon Vulture population, which is sedentary in Sardinia (Grussu 2001), is mainly attributable to the death of numerous individuals due to the illegal use by shepherds and breeders of carcasses of animals poisoned against stray dogs and Red Foxes Vulpes vulpes (Schenk et al. 2008). In the most recent period the population of Griffon Vultures in Sardinia has shown a progressive positive trend and has slightly increased from 29 pairs in 2011 to 45 pairs and a total population of 144-160 birds in 2017 (Campus 2017 and personal communication) which is equivalent to that present around 40 years ago. In 2015 a further project "Life Under Griffon Wings" (or LIFE14 NAT / IT / 000484) started in Sardinia to increase the present population by restocking with a total of 62 birds originating from Spain and released in the wild. The implementation of actions to reduce risks and disturbances towards the present population also took place. Thanks to this last project, the population of the Griffon Vulture has shown a significant increase; in 2019 in Sardinia were present 57 territorial pairs and a total of 230250 birds of the species (LIFE14 NAT / IT / 000484, F. Nurchi \& F. Campus personal communication).

The current breeding range of this species in Sardinia are highlighted in the Figure 4.

\section{Egyptian Vulture Neophron percnopterus}

The presence of the Egyptian Vulture in Sardinia is historically supported by Cetti (1882), but very few records were known until the end of the $20^{\text {th }}$ century (Grussu 2001). However, research in the museums of the world showed the presence of some birds (often in pairs) collected in the 19th century (Grussu unpublished). This discovery makes it likely that the species in that period was present on Sardinia with a small population; but there is no proof to support this. In the 2005-2020 period the Egyptian Vulture has then been recorded almost regularly with single migrants (Grussu unpublished), and in 2019 a pair has bred in the northwest of Sardinia close to a Griffon Vulture colony (F. Nurchi personal communication); this the first breeding record of the species on the island (Grussu \& Gruppo Ornitologico Sardo 2017, Nurchi in press).

\section{Reasons for the decline of vultures in Sardinia.}

The reasons for population declines of vultures are varied, but poisoning or human persecution, or both, feature on the list of nearly every declining species (Ogada et al. 2011). In Sardinia, the catastrophic vulture declines of the $20^{\text {th }}$ century (Table 1) have numerous causes; principally harvesting (collection of skins and eggs), followed by hunting, poaching, occasional killing and the use of poisoned baits (strychnine, arsenic compounds, DDT) for pest control (feral dogs, Red Fox, locust....). At the same time, since the early $20^{\text {th }}$ century in Sardinia, there has been a gradual decrease in pastoralism, which is associated with a general decline in livestock mortality and the improvement of hygienicsanitary conditions in the livestock sector, which has led to a reduction in food availability for necrophagous species. These causes have been accompanied by an increase in the human population and roads providing easier public access to island's wilderness areas leading to an increase of human disturbance at the breeding and roosting sites (Schenk et al. 2004, Grussu unpublished data, Sardinian Ornithological Group unpublished data). 


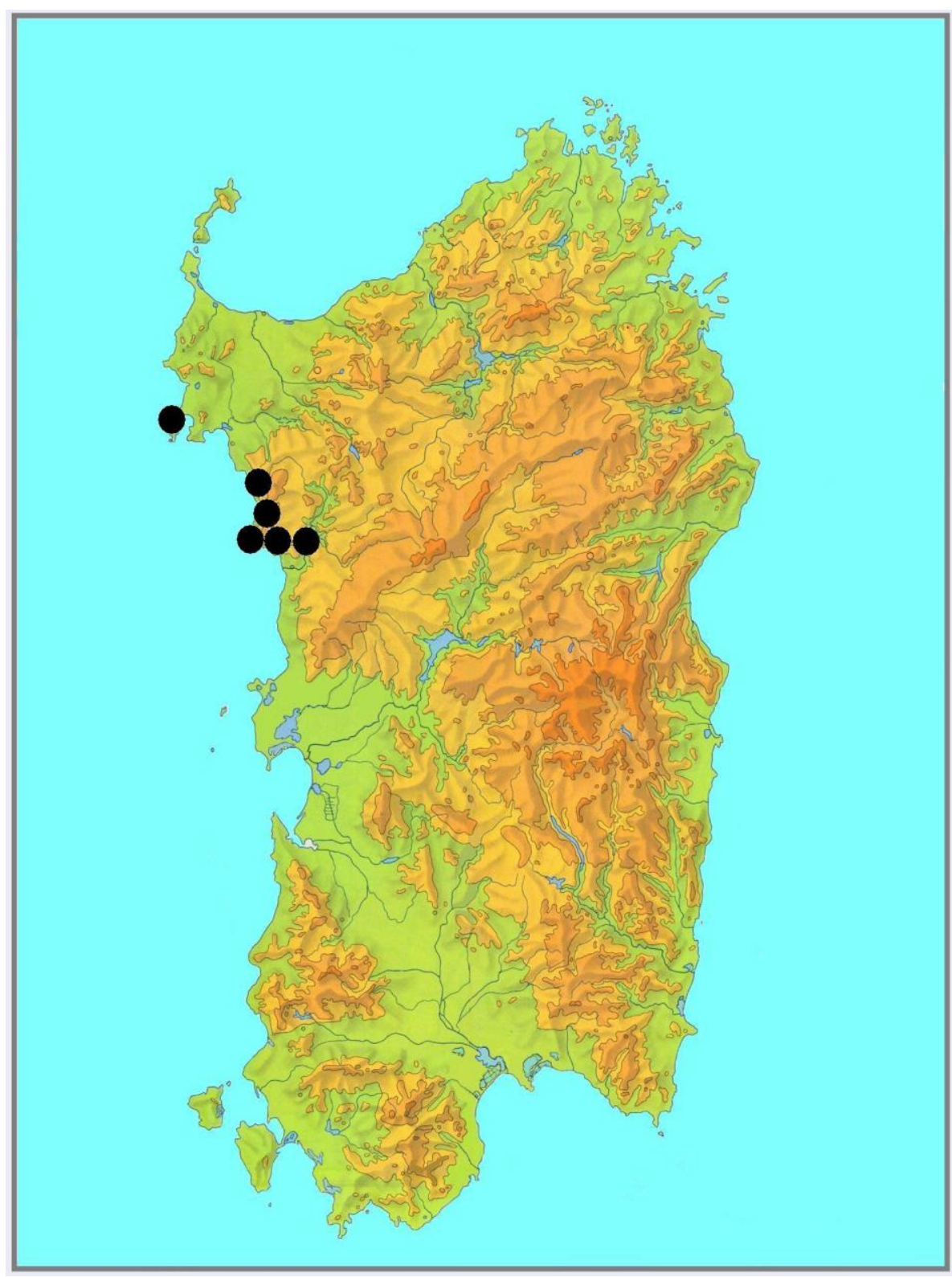

Figure 4: Current breeding colonies of Griffon Vulture Gyps fulvus in Sardinia.

About 140 specimens (mostly complete in other parts of the world (America, Europe, individuals, but also eggs and skeletons) of Australia, New Zealand) (Grussu unpublished). Bearded Vulture, collected during the period But the extinction of the Black Vulture is probably 1821-1962 in Sardinia are currently preserved in the European and North American Museums (Schenk et al. 2004, Grussu unpublished), and several tens of individuals of Black Vulture and Griffon Vulture are kept in museums in Italy and also due to the destruction of the island woodlands that were found in the late-1800s and the early decades of the 1900s, which led to a significant reduction of nesting habitat. 
Table 1: The evolution of vulture populations on Sardinia: 1800-2020.

\begin{tabular}{|c|c|c|c|c|c|c|c|}
\hline \multirow[b]{2}{*}{ Species } & \multicolumn{6}{|c|}{ Status/ population } & \multirow{2}{*}{ Note } \\
\hline & end 1800s & $\begin{array}{c}\text { beginning } \\
1900\end{array}$ & ca. 1950 & 1975 & 2000 & $2010-2020$ & \\
\hline $\begin{array}{l}\text { Bearded } \\
\text { Vulture }\end{array}$ & common & $\begin{array}{l}35 \text { pairs/ } \\
\text { ca } 125 \\
\text { ind. }\end{array}$ & 5-10 pairs & $\begin{array}{l}\text { Some } \\
\text { birds, last } \\
\text { breeding } \\
\text { record: } \\
1969\end{array}$ & $\begin{array}{l}\text { Extinct. } \\
\text { Last } \\
\text { observation: } \\
1972\end{array}$ & $\begin{array}{l}\text { Accidental; } \\
\text { with birds } \\
\text { coming } \\
\text { from } \\
\text { Corsica } \\
\text { Island }\end{array}$ & $\begin{array}{l}\text { One } \\
\text { reintroduction } \\
\text { project ( } 2008 \\
\text { year) failed }\end{array}$ \\
\hline $\begin{array}{l}\text { Black } \\
\text { Vulture }\end{array}$ & widespread & $\begin{array}{l}\text { ca } 150 \\
\text { pairs }\end{array}$ & $\begin{array}{l}25-35 \\
\text { pairs }\end{array}$ & $\begin{array}{l}\text { Some } \\
\text { birds, last } \\
\text { breeding } \\
\text { record: } \\
1961\end{array}$ & $\begin{array}{l}\text { Extinct. } \\
\text { Last } \\
\text { observation: } \\
1975\end{array}$ & $\begin{array}{l}\text { One } \\
\text { record; one } \\
\text { bird } \\
\text { coming } \\
\text { from } \\
\text { France }\end{array}$ & $\begin{array}{l}\text { Two birds } \\
\text { introduced in } \\
1981\end{array}$ \\
\hline $\begin{array}{l}\text { Griffon } \\
\text { Vulture }\end{array}$ & $\begin{array}{l}\text { very } \\
\text { common }\end{array}$ & $\begin{array}{l}\text { very } \\
\text { common }\end{array}$ & $\begin{array}{l}1000- \\
1400 \\
\text { birds }\end{array}$ & $\begin{array}{l}100-140 \\
\text { birds }\end{array}$ & $\begin{array}{l}23 \text { pairs and } \\
70-100 \\
\text { birds }\end{array}$ & $\begin{array}{l}57 \text { pairs } \\
\text { and } 230- \\
250 \text { birds } \\
(2019)\end{array}$ & $\begin{array}{l}\text { Several } \\
\text { restoking } \\
\text { projects: } \\
\text { 1986-2020 }\end{array}$ \\
\hline $\begin{array}{l}\text { Egyptian } \\
\text { Vulture }\end{array}$ & accidental & accidental & accidental & accidental & accidental & $\begin{array}{l}\text { migrant } \\
\text { rare; } \\
\text { first } \\
\text { breeding } \\
\text { record: } 1 \\
\text { pair (2019) }\end{array}$ & $\begin{array}{l}1 \text { pair present } \\
(2020)\end{array}$ \\
\hline
\end{tabular}


Regarding the Griffon Vulture, the project "The Life Under Griffon Wings" being carried out between 2015-2020 to protect and increase the small population of this vulture in Sardinia, in addition to providing a restocking operation, the release project has also realized several actions that will prepare future for reintroductions of the other vulture species such as:

- limit the shortage of carcass availability, with the creation of a network of controlled feeding stations with food free from any element or drug toxic to necrophages;

- the training of a dog unit to prevent and decrease the use of poisoned baits, that has been successfully tested in Spain (Garcia et al. 2011).
As of today, collection and killing of vultures, and legal use of poisoned baits have been removed in Sardinia. These aspects, the success of the project "The Life Under Griffon Wings" with the progressive increase in recent years in the Griffon Vulture population, the breeding in 2019 and the following wintering of a pair of Egyptian Vulture (normally the species is not wintering in Europe and in the Mediterranean - Cramp \& Simmons 1980, Forsman 1999), and the absence of recent "mass accidents" regarding the Griffon Vulture (Campus 2017), are hopeful sign of a "good" situation of the environment for the vultures in Sardinia, as well as for future projects of reintroduction of Bearded Vulture and Black Vulture in some areas of the island.

\section{Acknowledgements}

Special tanks for the collaboration and informations to Domenico Ruiu (Nuoro), Paolo Griva (Sassari), Jean-Francois Seguin (Corsica, Francia), Federico Nurchi, Fofo Campus and Pasquale Carroni (Bosa, Oristano), Guido Prola (Roma), Giorgio Virdis (Sestu, Cagliari) and Ugo Foscolo Foschi (Forlì).

Photographs (following page) 


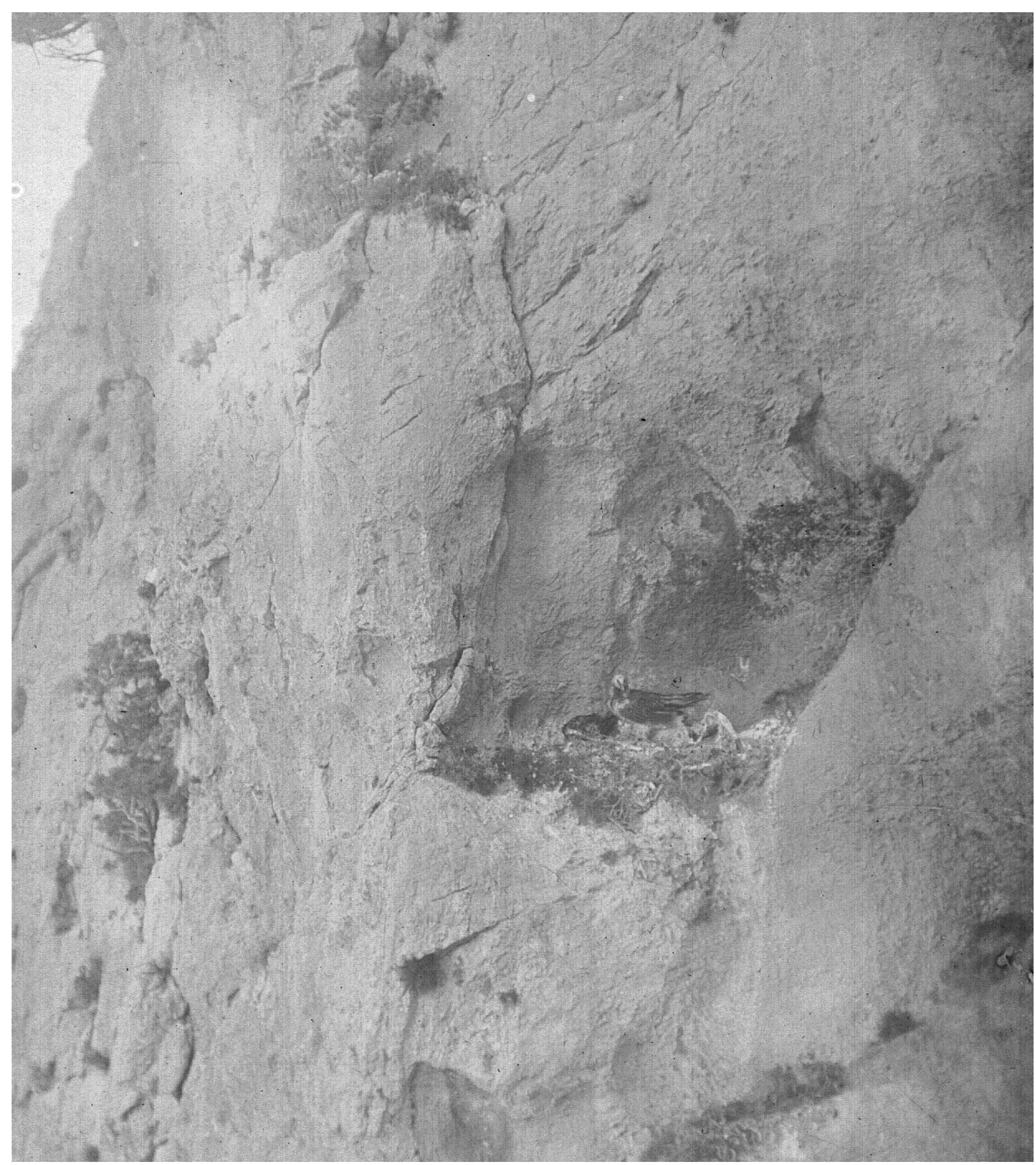

Photo 1: Adult and well-grown juvenile of Bearded Vulture Gypaetus barbatus in the nest in Sardinia, June 1926 (Carl Stemmler, GOS' collection). This images represent the only photographic report of one active nest of the Bearded Vulture in Sardinia and the first "historical photographic breeding record" for the species in whole Italy. 


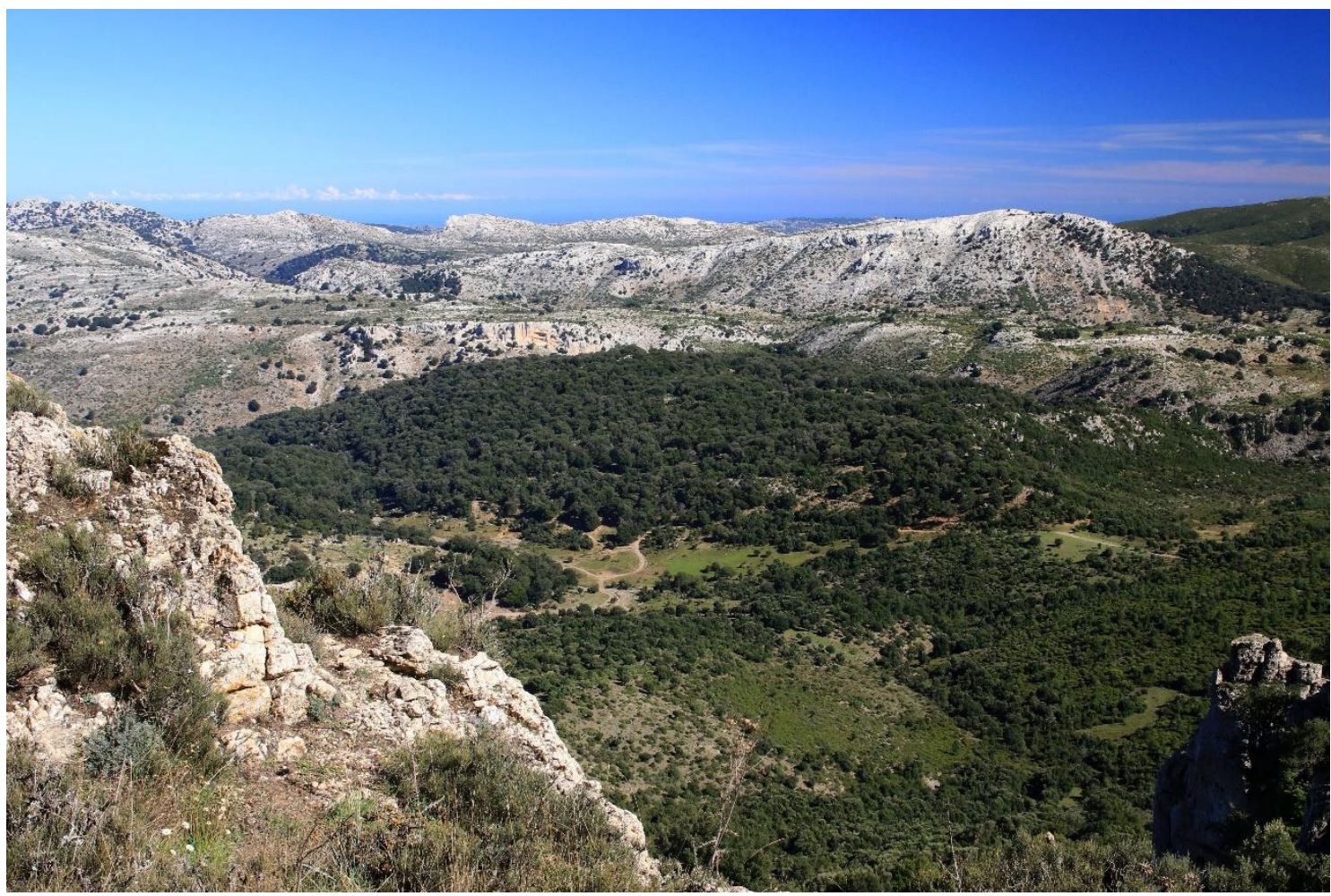

Photo 2: This area of central Sardinia until the mid-20th century was home to important populations of Bearded, Black and Griffon Vultures (Photo Gianni Sirigu).

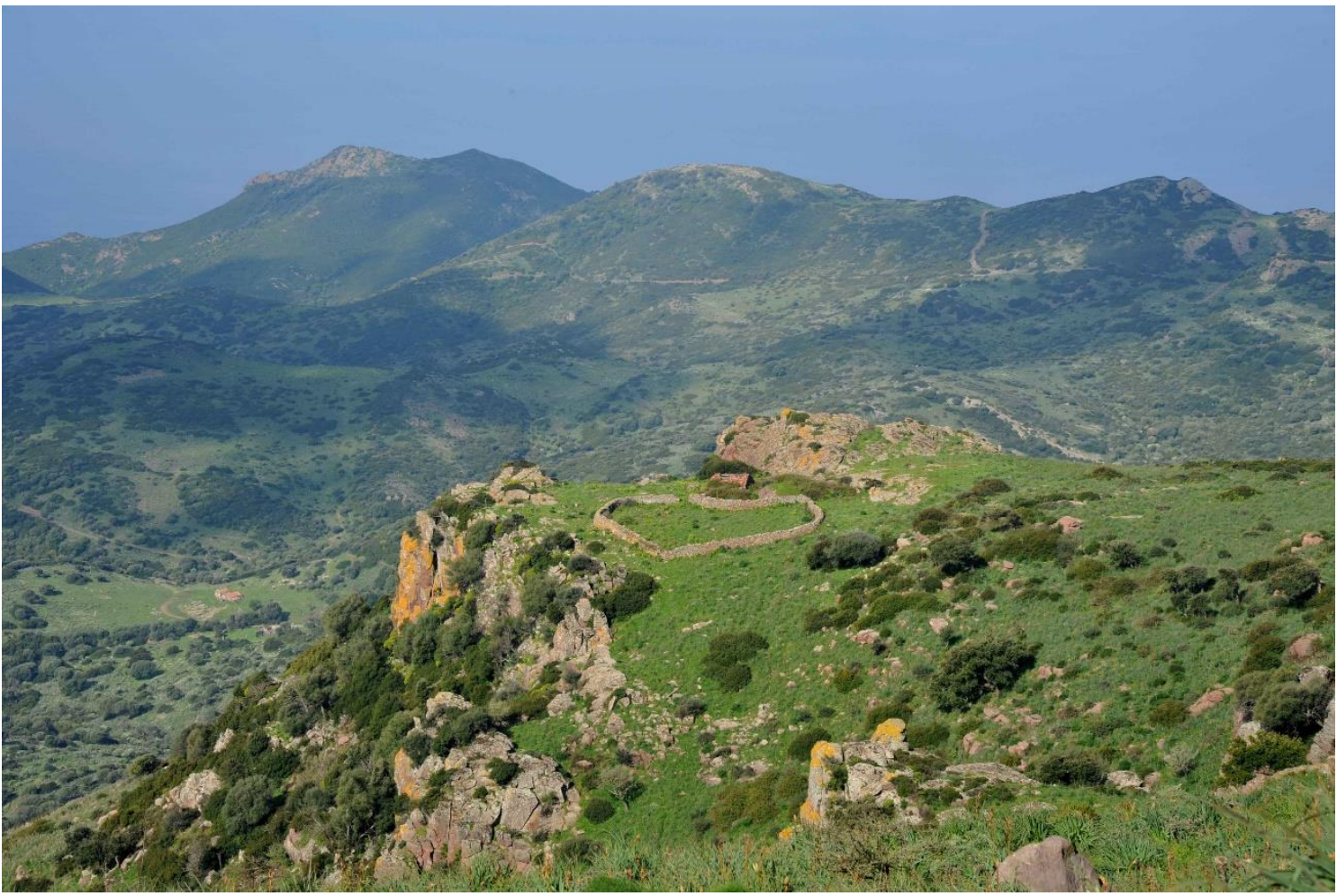

Photo 3: North-western of Sardinia, where the only population of Griffon Vulture suvives (Photo Oscar Mura). 


\section{References}

Arrigoni, P.V. 1968. Fitoclimatologia della Sardegna. Webbia 23: 1-100.

BirdLife International 2000. European bird populations: estimates and trends. BirdLife Conservation Series 10. Cambridge.

BirdLife International 2004. Birds in Europe. Population estimates, trends and conservation status. BirdLife Conservation Series 12. Cambridge.

BirdLife International 2018. State of the world's birds: taking the pulse of the planet. BirdLife International. Cambridge.

Brichetti, P., De Franceschi, P. \& Baccetti, N. 1982. Fauna d'Italia. Aves I. Calderini. Bologna.

Brichetti, P. \& Fracasso, G. 2003. Ornitologia italiana. Vol. 1. Gaviidae-Falconidae. Perdisa Editore. Bologna.

Brooke, A.B. 1873. Notes on the Ornithology of Sardinia. Ibis 3: 143-155.

Camarda, I., Laureti, L., Angelini, P., Capogrossi, R., Carta, L., Brunu, A., 2015. Il Sistema Carta della Natura della Sardegna. ISPRA Serie Rapporti, 222/2015.

Campus, A. 2017. La riproduzione del Grifone Gyps fulvus in Sardegna: periodo 2011-2016. Aves Ichnusae 11: 95-101.

Cara, G. 1842. Elenco degli Uccelli che trovansi nell'isola di Sardegna od Ornitologia Sarda. Flli Reycend \& C. Torino.

Cetti, F. 1776. Gli Uccelli di Sardegna. Piattoli. Cagliari.

Cramp S. \& Simmons K.E.L. 1980. The birds of the Western Palearctic. Vol. 2. Oxford University Press. Oxford. UK.

Ferguson-Lees J. \& Christie D. 2005. Raptors of the World. Helm.

Fasce, P. \& Fasce, L. 2009. Il progetto di reintroduzione del Gipeto Gypaetus barbatus in Sardegna. Aves Ichnusae 9: 62-65.

Fasce P., Fasce L. \& Torre J. 1989. Census and observations on the biology of the Bearded Vulture Gypaetus barbatus on the island of Corsica. Pp. 335-339 in: Meybur B.U. \& Chancellor R.D. (Eds.). Raptors in the Modern World. WWGBP. Berlin, London \& Paris.

Forsman D. 1999. The Raptors of Europe and the Middle East. T \& AD Poyser. London

Garcia, A.R., Garruta, A.V., Menzano, E.S. \& Garrido, F.M.M. 2011. La unidad canina especializada en la detección de venenos. Pp. 181-199 in: Fajardo, I. \& Martín, J. (Eds.). Manual para la protección legal de la biodiversidad para agentes de la autoridad ambiental en Andalucía. Consejería de Medio Ambiente. Seville.

Gautschi B. 2011. Conservation genetics of the Bearded Vulture Gypaetus barbatus. Thesis, University of Zurich. Switzerland.

Giglioli, E.H. 1890. Primo resoconto dei risultati dell'inchiesta ornitologica in Italia. Parte Seconda. Succ. Le Monnier. Firenze. 
Godoy J.A., Negro J.J., Hiraldo F. \& Donazar J.A. 2004. Phylogeography, genetic structure and diversity in the endangered Bearded Vulture Gypaetus barbatus L. as revealed by mitochondrial DNA. Molecular Ecology 13: 371-390.

Grussu M,. 2001. Checklist of the birds of Sardinia. Aves Ichnusae 4: 2-56.

Grussu, M. \& Seguin, J-F. 2015. Dispersion et déplacements du Gypaète barbu Gypaetus barbatus de Corse en Sardaigne. Alauda 83: 247-254.

Grussu M. \& Gruppo Ornitologico Sardo 2017. Gli uccelli nidificanti in Sardegna. Status, distribuzione e popolazione aggiornati al 2016. Aves Ichnusae 11: 3-49.

Hiraldo F., Delibes M. \& Calderon J. 1979. El Quebrantahuesos Gypaetus barbatus (L.). Monografias 22. ICONA. Madrid.

Iapichino, C. \& Massa, B. 1989. The birds of Sicily. BOU Check-list No. 11. British Ornithologist's Union. Tring.

Martorelli, G. 1884. Osservazioni sui Mammiferi e Uccelli fatte in Sardegna. Tip. Cino dei Frat. Brancali. Milano.

Nurchi, F. (in press). Nidificazione di Capovaccaio Neophron percnopterus in Sardegna. Alula

Ogada, D.L., Keesing, F.\& Virani, M.Z. 2011. Dropping dead: causes and consequences of vulture population declines worldwide. Annals of the New York Academy of Sciences 1249: 1-15.

Project LIFE 14 NAT/IT/000484. http://www.lifeundergriffonwings.eu/it/index.html , consulted on $4^{\text {th }}$ May 2020.

Salvadori, T. 1864. Catalogo degli Uccelli di Sardegna. Atti Società italiana Scienze Naturali VI. Milano.

Seguin, J-F. \& Grussu, M. 2017. Origine dei gipeti Gypaetus barbatus osservati di recente in Sardegna. Aves Ichnusae 11: 60-68.

Seguin J.-F., Torre J. \& Bretagnolle V. 2010. Distribution, population size and breeding parameters in the insular population of Bearded Vultures Gypaetus barbatus of Corsica over 28 years. Bird Study 57: 361-368.

Schenk, H. 1974. Situazione faunistica degli avvoltoi (Accipitriadae) in Sardegna. Pp. 63-69 in: AA.VV., Rapaci Oggi. LIPU, Parco Nazionale Gran Paradiso, WWF. Aosta.

Schenk, H. 1976. Analisi della situazione faunistica in Sardegna. Uccelli e Mammiferi. Pp. 565-556 in: Pedrotti, F. (a cura). S.O.S. Fauna. Animali in pericolo in Italia. Camerino.

Schenk H. \& Genero F. 1996. Rapporto finale "Progetto Grandi Avvoltoi”. LIPU \& RAS. Cagliari.

Schenk, H., Aresu M. \& Marras N. 2004. Feasibility study on the reintroduction of the Bearded Vulture (Gypaetus barbatus) in Sardinia. Pp. 80-104 in: Bearded Vulture Reintroduction into the Alps. Annual Report.

Schenk H., Aresu M. \& Naitana S. 2008. Proposta di un Piano d'Azione per il Grifone (Gyps fulvus) in Sardegna. Legambiente Sardegna.

$* * * * * *$ 